\title{
Formation of Sports Public Policy within the Context of Hierarchy Governance
}

\author{
Vilma Čingienė, Mindaugas Gobikas \\ Faculty of Public Governance, Mykolas Romeris University \\ Ateities str., 20, LT-08303 Vilnius

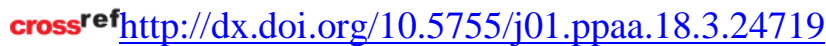

\begin{abstract}
This article aims to analyse the process of formation of sports public policy in Lithuania within the theoretical context of hierarchy governance. This study consisted of collection and analysis of official documents regarding sports public policy formation from 2011 until 2018. The data collection was aimed at uncovering of key components of the process of public policy formation - environmental analysis, strategic planning, competence and decision-making power, and stakeholders. The main findings of the research concluded that Lithuanian sports governance, along with the majority of other European countries, is defined as bureaucratic configuration. The main responsibility within the process of sports public policy formation falls on the Ministry of Education, Science and Sports and active national non-government sports organisations, while principal objectives of the Lithuanian sports public policy formation are laid out in strategic documents. However, the implementation needs to be centred on institutional and personal responsibility, proper environmental regard and tolerance, and the ability to listen and to reach an agreement.
\end{abstract}

Keywords: sports public policy, sports governance, hierarchy governance, policy formation process.

Raktažodžiai: viešoji sporto politika, sporto valdymas, hierarchijos valdysena, politikos formavimo procesas.

\section{Introduction}

Public policy is an essential function of government, as it reflects the actions of government, decision-making process and motives for decision implementation (Raipa, 2002). However, it is also the result of a significant number of individuals working together, since it's main objective is to solve common problems and address social challenges. As a result, it is important to note that the goal of public policy cannot be separated from its source.

Generally, four stages of public policy process are distinguished: formation, implementation, evaluation, and forecasting. All stages require the use of such political procedures as structuring of problems, policy monitoring, policy regulation, etc. (Raipa, 2010; Šerikova, 2013).

The process of public policy formation is an important step because it involves setting up an agenda and incorporating appropriate actors. The process is also defined by problem identification, intense negotiations between parties, and continuation even after the initial legislation has been passed.

Hierarchy mode of governance is based on division of labour and government control. This system favours compliance, efficiency, and predictability. The fundamental values of hierarchical form of management constitute control and subordination.

Sport as a subject of public policy has received limited attention in academic research. Hence, there is a shortage of initiatives regarding more thorough scientific investigations from those responsible for the formation and implementation of policy. More importantly, the sport management field lacks studies of comparative analysis in the area of sport and leisure policy (Henry et al., 2005). According to Houlihan (2005, p. 163), "there is remarkably little analysis of sport policy that utilises the major models and frameworks for analysis widely adopted in other policy areas". Consequently, national sport development policies in certain countries started to be analysed (Gree, Collins, 2008). 
More than a decade ago a special attention was given to the sport policy factors leading to international sporting success (De Bosscher et al., 2006) and vice versa, mechanisms of international influence on domestic elite sport policy (Houlihan, 2009). Currently, government involvement in the administration of high-performance sport remains of great interest (Gowthorp et al., 2017). At the same time the analysis of a specific aspects of sport policy, such as sport policy process interlinks with the legitimating acts (Strittmatter et al., 2018) and more common issues related to the sport public policy formation, evaluation and implementation (Osterlind, 2016; Lusted, 2018) poses continued interest of the scholars.

The role of sports and its economic impact is laid out in the first document by the European Commission regarding sports policy guidelines "White book on sports" (2007). However, the recognition of sports as a meaningful activity within the context of the European Union public policy gained some traction only with the Lisbon strategy.

This paper focuses on sport public policy formation process. Characteristics of Lithuanian sports system allow for it to be assigned under the category of bureaucratic configuration, which is mostly similar to the hierarchy governance. Thus, it is suggested here that the problem of research is to determine how the peculiarities of the Lithuanian sports system policy-making process are manifested in the context of hierarchical governance, correspond to the bureaucratic configuration and create objective preconditions for decentralisation.

The object of research is the expression of peculiarities of the policymaking process in the context of hierarchical governance.

This paper aims to analyse how the peculiarities of the Lithuanian sports system public policy-making process manifests itself in the context of hierarchical governance, corresponds to the bureaucratic configuration and creates objective preconditions for decentralisation.

\section{Theoretical framework}

According to Stone (2005), the most critical methods of public policy analysis are distinct definitions and its mechanical use by extrapolating them to the practice of policy analysis through realisation of the "hermeneutic" paradigm, based on various assumptions, combinations of arguments and policies. Dunn (2006) distinguishes two forms of public policy analysis: retrospective and perspective. This article presents a retrospective analysis of information generation and transformation while emphasising the variables of underlying problems after the policy has been implemented. The retrospective analysis of public policy formation should include the following components (Lindblom, Woodhouse, 1999; Parsons, 2001; Lane, 2005). First, it must involve the analysis of internal and external environment, characteristics of the public policy field, participants of the policy formation process, and characteristics of public ethics and general political culture. Second, the main focus must be addressed towards the components, stages and procedures of the policy process related to political factors, political, administrative, legal decision-making and implementation. Third, the emphasis must be placed on the components of the process of strategic state directions upon the formation of public policy, with the emphasis placed on the programs and projects in the process of public policy formation. Fourth, it needs to provide an analysis of the assurance of proper financial assignments for public policy formation.

Hierarchy governance. This type of governance is distinguished by bureaucratic regulations, administrative apparatus, authority and subordination. Economic model of hierarchy governance describes subordinate employee who has no ownership rights over manufactured product and receives compensation depending on time spent, experience, and necessary skills. It is important to note that an employee does not bear the risk of poor results, nor does he/she receive an additional bonus for successful achievements. Organisational management studies (Staniulienė, 2008; Makadok, Coff, 2009) demonstrate that the effectiveness of performed operations distinguishes the institutional structure of hierarchical mechanism. Noticeably, the efficiency is achieved through the division of activities into routine tasks. 
The hierarchy governance occurs when boundaries of company expand, and the company itself starts to carry out the activities previously performed by external participants (market). Thus, the visible hand of managers replaces the invisible hand of the market by coordinating demand and supply fluctuations. In the hierarchical structure, the activities of the employees are regulated by administrative procedures and the positions of employees, which are determined by senior managers. Management separates activities and jobs and creates a system of authoritarian arrangements. Since the tasks performed are quite often highly specialised, the activities are not related to each other and are independent of each other. As Powell (1990) describes, a large, vertically integrated company is an exceptionally socially integrated institution with its routine, expectations and specific knowledge.

In hierarchy governance, knowledge is seen as a scarce resource. Therefore, expertise, along with the relevant decision-making rights, is concentrated in specialised, higher-level functional units of organisation. Academics (Powell, 1990; Staniuliene, 2008; Makadok, Coff, 2009) agree that the main advantages of hierarchy governance are subordination, specialisation, security (resulting from clarity), and reduction of responsibility. Meanwhile, the essential shortcomings of the hierarchy are the lack of self-realisation, the method of remuneration based on post, not the qualities, and the lack of innovation. DiMaggio and Powell (1983) emphasise that reliability and accountability are essential hierarchical structures. Reliability refers to the ability to manufacture quality products or services continuously, and accountability refers to the ability to document the use of resources.

However, organisations operating within the hierarchy governance face unbearable difficulties when it comes to innovation or the acquisition of new knowledge. In situations such as the development of a new product, where specialised units are faced with unexpected problems requiring unusual solutions, the hierarchical structure provides very little leverage for senior managers to ensure the collaboration between participating units. Due to a non-routine nature, such tasks cannot be programmed, and creative cooperation, which is required to solve such tasks, cannot be so easily implemented. As can be seen, the effectiveness of vertical integration drops dramatically, when tasks are non-routine, as lower-level employees lack both the ability to generate new knowledge and the incentives to transfer that knowledge. In this way, companies may be forced to look for substitutes for the leading hierarchy governance operation state, which would make it possible to reduce the weaknesses of this system.

At the state level, good governance in a hierarchical system is considered to be one where the governing authorities have all the necessary conditions to determine what best fits the "public interest". According to Dixon and Dogan (2002, p. 179-180), governors seek to protect the public interest by imposing rights and obligations on the governed. Thus, the expected behaviour is compliance based on rational calculations and commitment. As a result, it is essential to note that the greatest threat to the hierarchical governance mode is considered to be the loss of control.

Sports governance in Lithuania. As provided by the report on the improving employment in the field of sport in Europe through vocational training (VOCASPORT Research Group, 2004, p. 53), bureaucratic configuration is largely dominant form of sports governance throughout Europe. Research group agreed upon several key categories, according to which four configurations of European sports systems emerged. First, it was looked into what role that public authorities, particularly ministries, played in the regulation of sports system. Second category involved the degree and form of coordination between those involved in sports regulation system. Third, it was looked into the distribution between the three types of sports providers: public, private, and voluntary. Fourth parameter was the suitability of the supply to the changes in demand.

Based on the aforementioned key categories four distinctive configurations of sports governance - bureaucratic, missionary, entrepreneurial, and social - were discovered in European countries. According to the research, Lithuania has been assigned to the bureaucratic configuration along with the majority of other European counterparts (16 out of 25 countries).

The bureaucratic configuration is characterized by the active role of public authorities and highlighted by the legislative framework specific to the field (law on sport). Additionally, the focus is placed on the verification of standards and systems, and the attention is paid to the process but not 
to the outcomes. According to Henry (2009, p. 42-43), such system is fully comprised of rules imposed by the public authority, which does not necessary negotiate to any great extent with other sector stakeholders. Research concludes that voluntary sports movement acts by delegation, social partners are often non-existent, and consumers, as well as private entrepreneurs, have a low impact on the implementation of sports policy.

\section{Data and methods}

Research presented in this article has been conducted using the methodological framework on the analysis of the process of public policy formation as provided by Lindblom, Woodhouse (1999), Parsons (2001) and Lane (2005). As outlined earlier, the key components of the process of public policy formation are environmental analysis, competence and decision making power, strategic planning, and stakeholders. As a result, all these components were analysed and identified using information obtained through these sources - laws and bylaws, government regulations, documents of public sector organisations, database of sports statistics. Publication dates of gathered documents ranged from 2011 till 2018. The collection of data was performed during May-November, 2018. Collected data were grouped and categorised, thus, enabling the complete map out of situation of public policy formation.

\section{Research findings}

Concept of sports public policy. Sports, as a social and cultural phenomenon, encompasses knowledge systems, certain activity forms and sports organisations that implement those activities within timely and spatial constraints (Laskiene, 2003, p. 40). Participant is the axis of sports system: both active (engaged into sports activity of his/her liking and seeking certain benefits from it) and passive (fan of particular sports or simple viewer). The evolution, organisation, management and development perspectives of Lithuanian sports system has been a constant object of international research, especially within the framework of various international projects (Čingiené, Gobikas, 2011, p. 139-156; Čingienè, 2017, p. 179-199). The recognition of sports as an integral part of national identity development (Čingienè, Laskienè, 2004, p. 762-765), as well as the expression of country's "soft power" (Čingienè et al., 2014, p. 264) has been increasingly evident. Upon evaluation of contemporary societal structure, the perennial question is being raised about who is responsible for the evolution of Lithuanian sports. More importantly, according to Genys (2014, p. 50-51), how dominant and hegemonic normative that have encapsulated sports management impacts state sports and conforms to the strategic interests of society.

Public sports administration is distinguished by a variety of different forms across the European countries. Depending on the degree of intervention, it can be a ministry, which is directly responsible for sports (France, Luxembourg), or it can be a secretariat linked with Ministry of Education, Culture or Tourism (Germany, Greece, Ireland, Netherlands, Portugal, Poland, Latvia, Estonia). Countries that do not have a department responsible for the governance of sports provide financial assistance for independent institutions (sports councils) through different ministry departments (United Kingdom) or have a cooperative association (for example, with National Olympic Committee), which is assigned a mission of public good (Italy). Many developed countries have sports firmly established within the government mechanisms, programs of political parties and discussions, as well as expectations, of voting citizens. Government involvement in sports is coupled with four main objectives: health, social control and relationship, diplomacy, and economic development (Houlihan, 2009, p. 255).

Environmental analysis. The internal environment of the formation of sports public policy in Lithuania should be examined using internal system SWOT (strengths, weaknesses, opportunities and threats) analysis as provided by the National Sports Development Strategy 2011-2020 (further Strategy), which revolves around various sports development issues. It must be emphasized that Strategy aspects have both direct and indirect impact on the formation process of public policy. 
Strategy strengths highlight the development of result-oriented sports, explicate institutional network, resource availability, and positive public opinion. On the other hand, the lack of institutional cooperation, insufficient valuation of private sector's role, and minuscule state input in promotion of physical activity are named as weaknesses of sports public policy formation. The development of infrastructure and action programs are seen as core opportunities for the development of sports system, while operations of municipal institutions and optimisation of sports employees' conditions are identified as threats to the process of sports public policy formation. External environment of Lithuanian sports public policy formation will be presented through PESTEL (political, economic, social, technological, ecological and legal) analysis.

Political environment. State political situation, provisions of programs by political parties, government programs and municipal strategic development plans all have a direct impact on sports system development. Tamulaitienè and Norkus (2012) performed the comparative analysis of regulations prepared by the Lithuanian political parties for the election of 2008-2012 Parliament and the program of the Government of the Republic of Lithuania (LRV). Research showed that developmental objectives of political parties only partially corresponded with the LRV program, which was largely based on social function and societal developmental factors of sports. However, programs of political parties in 2012-2016 demonstrated different interests and continuity of assumed commitments upon implementation of sports policy (Mizeras, Norkus, 2016, p. 68-69).

Economic environment. The development of sport system is directly impacted by the state's financial situation, the dynamics of the GDP, employment rates, and foreign investments. 2013 market the beginnings of evaluation of sports economic impact studies (Čingienè, Laskienè, 2013, p. 8-9). According to the state department of statistics (Sporto ekonominiai rodikliai 2015 m., 2016), sports sector produced $1.5 \%$ more added value in 2015 than in 2014, which accounted for $262.2 \mathrm{mln}$. EUR ( $0.8 \%$ total added value of Lithuania). Total amount of sports sector production in 2015 was 422.1 M EUR; while 18.5 thousand people were employed in the sector, which accounted for $1.4 \%$ of all working population. 2014 research revealed the consumer habits of Lithuanian citizens in the sports sector (Čingiené, 2015, p. 4-5).

Social environment. Sport as a part of general culture plays a vital role in the life of the individual and society. Traditions, leisure hobbies, health promotion and other social factors determine the form, frequency and intensity of participation in sports activities. Personality development, school relations inside and outside school, gender equality, social integration, special needs groups, organisation values management and other topical issues are an integral part of the sport's social environment. The dual career of the athletes become important issue of the sports sector. However, the support system is still missing at the national level (Treigienè, Šukys, 2019). Increasingly negative factors of modern society that influence the development of sports activities, such as manipulation of sports competitions (Bistrickaite, 2015, p. 68-69), corruption (Zaksaitè, 2015, pp. 10-13), and use of doping are being observed.

Technological environment. Technological development, implementation of innovations, development of sports-health clusters, modern communication and public information tools and other factors determine the environmental conditions of training and competing in the sports system and especially in high-level sports. Study on clusters (Klasteriu studija, 2012) indicates two existing clusters in Lithuanian sports sector: iVita and International Wellness Cluster. Gaming industry and esport are becoming an important part of the activity of clubs and leagues (Čiupaila, Abromavičius, 2017).

Ecological environment. The ultimate goal of sports activities is to create a favourable environment and opportunities for all to cultivate sport. Efforts to preserve the environment through organised sports activities by creating open spaces for physical activity, building or reconstructing sports facilities, especially during major sporting events, are a topical issue in shaping sports public policy (Mikalauskas et al., 2016). Commissions, advisory working groups are being set up to make important decisions on preserving the environment and harmonising the conditions for sports activities. 
Legal environment. The development of sport legal relations in the country's legislative system and the solution of specific situations include the regulation of the activities of sports organizations, the organization and management of professional sports (contracts, agency activities, disputes, international conflicts, violation of human rights, regulation of the transfer of athletes from club to club, etc.). Although the legal status of a professional athlete in Lithuania has been studied for quite some time (Valasevičius, 2004), several key issues, namely athlete representation by agents and unions, have hardly been subject of any research.

Agreements on match-fixing in Lithuanian sport (manipulation of sports results) have become a very topical issue. Although the first events were already recorded in 2011 (Zaksaitè, 2013), only in 2017 the Article 182 "Manipulation of Sports Competitions" of the Criminal Code of the Republic of Lithuania came into force. A special attention by the government was given to sport and legal issues during the World Intellectual Property Organization (WIPO) regional conference on Intellectual property and sports, held in Lithuania. The value of intellectual property within the sport industry, abuse and misuse of intellectual property in sport, copyrights and other issues were discussed (Latest news, 2016). The existing legal practice and professional competence of specialists contribute to the establishment of legal framework in the country.

The sports public policy consists of the following components: national and municipal authorities, operational programs and projects, legal regulations and documents, resources: buildings and infrastructure, finance and investment, professionals and volunteers. However, the most important component of a sports system is a participant in sports activities. We describe the sport participant according to his/her age, gender, education, social status, etc. However, it is worth emphasising that by far, the crucial component here is the participant's motivation to engage in a particular sport or any form of physical activity. Participant's motivation varies, i.e. strive for sport results, improve his/her body, communicate and discover friends, peers, improve health, and so on. (Kromerova, Šukys, 2016). The participant's sports activities may have a two-fold socio-economic dimension: active and passive.

Competence and decision making power. The Law of Sports of Lithuanian Republic (2018) defines competencies of government and municipal institutions in the sports sector. Parliament performs policy formation at the national level, Government, National Sports Council and, ministries (Education and Science, Health, etc.), and other state institutions (Department of Statistics, etc.). According to the latest edition of the Law of Sports, the Ministry of Education and Science was reformed into the Ministry of Education, Science and Sports and was solely responsible for the sports policy formation, coordination and implementation at the state level. At the municipal level, it is up to city and county departments of physical education and sports to form and implement sports public policy. It is worth mentioning that the municipality administrations are establishing nongovernmental organisations upon the formation of sports public policy. For example, on February 13, 2008, Vilnius city council recommended and obligated the establishment of Vilnius city sports council, which would be responsible for the formation of municipal sports policy following strategic sports plans and annual programs, as well as the implementation of such policy.

National non-governmental sports organisations, such as Lithuanian National Olympic Committee (LTOK), Lithuanian Association of Sports Federations (LSFS), Lithuanian Association of Sport for All, are also involved in the formation of public sports policy. These are umbrella organisations, which accept their memberships under their regulations and provide certain services to their members based on mutually beneficial agreements. Various associations participate in dialogue with state sports and other institutions according to their purposes and roles, representing the interests of their members.

The place of political decisions in the formation of sports public policy is manifested through the sports-oriented public activities of individuals or institutions. There are two opposing approaches to sports public policy (Guldenpfenning, 2000, p.125-129). First, sports as a policy tool - sports activities are used as aspects of social integration, public education, health promotion, creation and nurturing of positive image of the country. Second, sport as a politically free option - sports planning 
and decision-making is essential in both national and foreign sport policy. Sport policy is also becoming an increasingly important part of sport social science as a significant part of the sociology of sport.

Strategic planning process. After the restoration of Independence on March 11, 1990, the governance of Lithuanian sports sector was transformed into the European model, which is defined by the leading documents of the European Commission: European Charter for Sport, European Charter for Sports for All, European Code of Ethics in Sport, Anti-Doping Convention, and European Convention on Brutal Conduct of Fans. Article 53 of the Constitution of the Republic of Lithuania (1992) states that Government motivates society to participate in physical education and promotes sports. Four sports congresses were organized in 1992, 1996, 2000 and 2005 in order to promote the formation of sports public policy, to discuss topical issues of sports system development and to foresee future perspectives. In 2000 for the first time since the restoration of Lithuania's independence, the Sports Congress adopted the "Lithuanian Strategy for Physical Education and Sport for 2000-2012". In 2005 the document on the development of sports activities was renewed, and the "Lithuanian Strategy for Physical Education and Sport 2005-2015" was adopted. However, the Parliament of Lithuania did not accept this strategy. Nevertheless, changes in political, administrative and economic structure of the country lead to the approval of State Sports Development Strategy 2011-2020 (on March 24, 2011). In 2014 the government approved the interinstitutional Action Plan for 2015-2017.

In 2015 the process of strategic planning in the internal affairs system was started by involving the heads of institutions and divisions of management areas assigned to the ministry. Therefore in 2016, not only the priorities of the activity have been actualised, but also the new strategic action plan, priorities, strategic goals, objectives and indicators, target changes and criteria for their evaluation were prepared. According to the law regulating the composition of State budget, governmental assignments are delegated for the following state needs: education, culture, health care and sports programs. As a result, it could be stated that the process of program-based formation of sports public policy has only begun in 2011.

Subjects of physical education and sports operating in Lithuania are financially dependent on state regulation and allocations of state and municipal funds. Funding for the formation of sports public policy is secured each year through direct subsidies for the development of sport from the national budget. In addition, different ministries have some budgeted spending designated for sporting activities. Since the function of the development of physical education and sports is attributed to the autonomous decisions of the municipality, each municipality - by the decision of its council allocates funding for the development of sport within a particular region. Funding priorities and expenditures depend on the traditions, the popularity, the development of infrastructure, the extent, frequency and, significantly, political will of participation in sport, i.e. the attitude of the municipal council members or leaders towards a particular sport or sports in general. For example, in 2014, the expenditures on programs run by the state were estimated at over $20 \mathrm{mln}$. EUR, while municipality run programs amounted for $52.9 \mathrm{mln}$. EUR. The contribution of Vilnius and Kaunas municipalities accounted for more than one third $(31.3 \%)$ of all the sport development expenditures by all municipalities (60).

Stakeholders. The role of stakeholders is particularly important during the process of sports public policy formation. According to Ferrand et al. (2012, p.36-40), stakeholders can be categorized into two different groups: primary and secondary stakeholders. Primary stakeholders are involved in the formation of sports public policy, and their involvement is essential for the survival and development of the organisation. The secondary stakeholders are able to influence this process, but they are not essential to the accomplishment of organisation's mission.

The influence of officially registered lobbyists is not significant. Lobbyists mainly work in the areas related to sport, i.e. when the aim was to change the regulation of alcohol advertising; regulation of gambling taxation and so on. However, active involvement of informal lobbyists, i.e. 
non-governmental sports organisations and individuals representing them with personal aspirations, are increasingly evident.

It is worth mentioning that systematic monitoring, auditing, control, expert and expert systems and public participation are largely absent during the formation of sports public policy. On the one hand, the country's sport is still underrepresented as a significant socio-economic area, while on the other hand, lack of monitoring and control systems creates an environment for various negative phenomena for which sports activities are particularly susceptible. It should be noted that the public audit to assess the effectiveness of the development of physical education and sport was carried out for the first time only in 2009. The results of audit showed that in the absence of approved state sports strategies and institutions with sufficient authority to coordinate the development of physical education and sport at national level, the activities were not coordinated, lack of inter-institutional cooperation existed, only individual programs and projects were financed, and the objectives of the programs often overlapped.

According to Strittmatter et al. (2018), sport policy processes in practice rely primarily on organisations and organisational action. Therefore, regulatory changes in the process of formation of sports public policy are essential. They determine the development capacity of the sports system, the competence of the institutions and their leaders, the harmony of interests and the value obligations. However, the quality of organisational change depends mainly on stakeholder communication, interinstitutional and inter-sectoral cooperation, transparency and fairness, leadership and personal and institutional responsibility.

The personnel structure of all organisations participating in the process of sports public policy formation distinguishes in professional diversity. The staff responsible for sport policy formation are civil servants. The administrative decisions establish the municipal sports departments and athletes' training centres. Skills and qualities of all staff members are developed in the process of continuous qualification improvement. Different occupations have different regulations for qualification development. Annual employee performance appraisals are also conducted each year when the employee discusses the lack of competencies and the necessary training to develop them with the head of the institution. The coaches of the athletes' training centres must follow the approved procedure for the improvement of the qualification of physical education and sports specialists approved by Law of Sports (2018).

\section{Conclusions}

1. Hierarchy governance is based on division of labour, government control and the subordination. Within this system compliance, efficiency, and predictability are the most highly valued characteristics. The main weakness of hierarchy governance is its inability to adapt to innovations and to encourage the emergence of new knowledge.

2. Lithuanian sports governance, along with the majority of other European countries, is defined as bureaucratic configuration and characterised by the active role of State and the existence of sports-specific legislative framework. Over the last three decades, the process of the sports public policy formation has been conditioned by the context of hierarchy governance. Due to the structural changes, the primary responsibility falls on the Ministry of Education, Science and Sports. Active involvement of national non-government sports organisations and their aspirations for the autonomy lays a significant background towards decentralisation. Agreements on essential questions and constant organisation of open discussions are pivotal conditions for institutional interaction and crosssectoral collaboration.

3. Lithuanian sports system is fully comprised of rules imposed by the public authorities. Principal objectives of the Lithuanian sports public policy formation are laid out in sports development strategy of the state 2011-2020. The strategy is based on the analysis of internal environment, at the same time paying significant attention to the ever-changing external environment. Sport remains an essential instrument of political parties to gain the promotion of high-level 
performance, while the general population displays increasing levels of physical activity, healthy lifestyle and well-being.

4. Despite the abundance of public structures, interest groups and associated organisations within the state sports system, their actions concerning sports public policy formation are rather fragmented. This situation is largely caused by the lack of competence, inconsistent activities and shortage of concord between public and private interest. Sports as global public good should be developed on transparency and compose the interests of all stakeholder groups.

\section{Acknowledgement}

Authors express gratitude to Prof. Alvydas Raipa for the inspiration to investigate relevant issues of the national public sports policy and for continuous debate and professional development.

\section{References}

1. Bistrickaite, R. (2015). Manipuliacijos sporto varžybomis - iššūkiai Lietuvai ir tarptautinei bendruomenei. Sporto mokslas, 2 (80), 67-76.

2. Čingienè, V. \& Gobikas, M. (2012). Sport in Lithuania. In: C. Sobry and D. Mastrogiannakis (eds.) Sports Governance in the World: A Socio-Historic Approach. Volume II. The Transition in Central and Eastern European Sport. Paris, France, Editions Le Manuscript, 139-156.

3. Čingienè, V., Laskienè, S. (2004). A Revitalized Dream: Basketball and National Identity in Lithuania. The International Journal of the History of Sport, 21 (5), 762-779.

4. Čingienė, V., Damijonaitis, M.; Komskienè, D. (2014). Soft Power Index Extension: The Case of the Influence of Lithuanian Basketball. Transformations in Business \& Economics, Vol.13 $(2 \mathrm{~A}, 32 \mathrm{~A}), 462-482$.

5. Čingienè, V., Laskienè, S. (2013). Ekonominio sporto rinkos poveikio šalies ūkiui analizès turinys ir aktualumas. Sporto mokslas, 3 (73), 8-12.

6. Čingienè, V. (2015). Lietuvos gyventojų vartojimo išlaidų sporto sektoriuje tyrimo rezultatų ataskaita. Kaunas: Unikom.

7. Čingienė, V., Laskienè, S., Raipa, A. (2015). Gero viešojo valdymo principų ịgyvendinimas: Lietuvos strateginių sporto šakų federacijų atvejis. Public Policy and Administration, 14 (4), 501-514.

8. Čingienè, V. (2017). Lithuania: Organisation and Governance of Sport. In: J. Scheerder et al. Sport Policy Systems and Sport Federations. London: Palgrave, 179-199.

9. Čiupaila, P., Abromavičius, E. (2017). Video žaidimų industrijos plètotė: teorinis aspektas. Aukštujų mokyklų vaidmuo visuomenėje: iššūkiai, tendencijos ir perspektyvos. Alytus: Alytaus kolegija,1 (6), 14-17.

10. De Bosscher, V., De Knop, P., Van Bottenburg, M., \& Shibli, S. (2006). A conceptual framework for analysing sports policy factors leading to international sporting success. European Sport Management Quarterly, 6 (2), 185-215.

11. Dunn, W. (2006). Viešosios politikos analizè: juadas. Vilnius: HOMO LIBER.

12. Genys, D. (2014). Kas valdo Lietuvos sporto raidą? Sporto mokslas. 4 (78), 50-58.

13. European Commission. White paper on sport. (2007). http://ec.europa.eu/sport/whitepaper/white-paper_en.htm [2018-10-15]

14. Green, M., Collins, Sh. (2008). Policy, politics and path dependency: sport development in Australia and Finland. Sport Management Review.11 (3), 225-251.

15. Gowthorp, L., Toohey, K., \&Skinner, J. (2017). Government involvement in high performance sport: An Australian national sporting organization perspective. International Journal of Sport Policy and Politics, 9 (1), 153-171.

16. Henry, I. (2009). European models of sport: governance, organizational change and sports policy in the EU. Hitotsubashi Journal of Arts and Sciences, 50, 41-52. 
17. Henry, I., Amara, M., Al-Tauqi, M., Lee, P. C. (2005). A typology of approaches to comparative analysis of sports policy. Journal of Sport Management, 19, 480-496.

18. Houlihan, B. (2005). Public sector sport policy: developing a framework for analysis. International review for the sociology of sport, 40 (2), 163-185.

19. Houlihan, B. (2009). Mechanisms of international influence on domestic elite sport policy. International Journal of Sport Policy and Politics, 1 (1), 51-69.

20. Houlihan, B. (2009). Government Objectives and Sport. In: W. Andreff and S. Szymanski, (eds.). Handbook on the Economics of Sport. Cheltenham: Edward Elgar Publishing, 256-259.

21. Klasteriu studija. (2012). Vilnius, Lithuania. http://www.klaster.lt/uploads/documents /Klasteriu_studija_2012.pdf

22. Kromerova, E., Šukys, S. (2016). Adolescent involvement in sports activities and internalization of moral values. Baltic journal of sport \& health sciences. 1 (100), 22-30.

23. Lane, J. E. (2005). Public administration and public management: the principal-agent perspective. London: New York (N.Y.): Routledge: Taylor \& Francis Group

24. Latest news. (2016). http://ipconference.1t/2016/03/17/e500-million-lost-every-year-throughoutthe-eu-due-to-fake-sports-equipment/

25. Lindblom, Ch.E., Woodhouse, E.J. (1999). Politikos formavimo procesas. Vilnius: Algarvè.

26. LR sporto istatymas. $2018 \mathrm{~m}$. spalio $18 \mathrm{~d}$. Nr. XIII-1540. https://www.etar.lt/portal/lt/legalAct/a55037d0dcd611e89a31865acf012092 [2018-12-05]

27. Lusted, J. (2018). A critical realist morphogenetic approach to researching sport policy: reflections on a large-scale study of policy implementation in grassroots English football. International Journal of Sport Policy and Politics, 10 (4), 705-714.

28. Nutarimas dèl 2011-2020 metų valstybinès sporto plètros strategijos patvirtinimo. https://www.e-tar.lt/portal/lt/legalAct/TAR.5149504F601C [2018-11-15]

29. Mizeras, R., Norkus, S. (2016). Sporto raiška Lietuvos politinių partijų, pretenduojančiu patekti i Lietuvos Respublikos Seimą 2016-2020 m. kadencijai, programose. Sporto mokslas, 3(85), 6673

30. Mikalauskas, R., Šimkus, A., Brusokas, A. (2016). Sporto vadyba: nuo sportinès veiklos teorinès paradigmos iki savanoriškos veiklos: monografija. Kaunas: ARX reklama.

31. Osterlind, M. (2016). Sport policy evaluation and governing participation in sport: governmental problematics of democracy and health. International Journal of Sport Policy and Politics, 8 (3), 347-362.

32. Tamulaitienė, R., Norkus, S. (2012). Lietuvos politinių partijų sporto politicos programinių nuostatų analizè. Sporto mokslas, 1 (67), 19-26

33. Parson, W. (2001). Viešoji politika: politikos analizės teorijos ir praktikos įvadas. Vilnius: Eugrimas.

34. Raipa, A. (2002). Viešoji politika ir viešasis administravimas: raida, struktūra ir sąveika. Viešoji politika ir administravimas, 1, 11-20.

35. Raipa, A. (2010). Politikos ir administravimo sąveika viešajame valdyme. In: V.Smalskys (eds.) Viě̌asis valdymas. Vilnius: MRU, 152-163.

36. Rezoliucija „Dèl nevyriausybinio sporto plètotėsLietuvoje ir savireguliacijos“. Priimta $2016 \mathrm{~m}$. gegužès 12 d. Lietuvos nevyriausybinių sporto organizacijų forume. http://ltok.lt/naujienos-irmedia/aktualijos/show/posedziavo-lietuvos-sporto-prezidentu-taryba [ 2018-11-15]

37. Stone, D. (2005). Viešosios politicos paradoksai: sprendimu priemimo menaspolitikoje. Vilnius: Eugrimas.

38. Strittmatter, A., Stenling, C., Fahlén, J., Skille, E. (2018). Sport policy analysis revisited: the sport policy process as an interlinked chain of legitimating acts. International Journal of Sport Policy and Politics, 10 (4), 621-635.

39. Šerikova, A. (2013). Viešoji politika ir jos formavimas. In: D. Šaparnienė and A. Krupavičius (eds.). Viešasis valdymas: koncepcijos ir dimensijos. Vilnius: BMK leidykla, 23-39. 
40. Treigienè, M., Šukys, S. (2019). Sportinès karjeros baigties ir po jos analizè. Laisvalaikio tyrimai: elektroninis mokslo žurnalas. 1 (13), 1-7.

41. Zaksaite, S. (2013). Match-fixing: the shifting interplay between tactics, disciplinary offence and crime. The International Sports Law Journal. 13 (3), 287-293.

42. Zaksaitè, S. (2015). Apgaulè sporto srityje: teisinis ir kriminologinis požiūris. Vilnius: MRU.

43. Valasevičius, S. (2004). Profesionaliojo sportininko teisinis statusas Lietuvoje. Ugdymas. Küno kultūra. Sportas. 2 (52), 85-90

44. VOCASPORT Research Group. (2004). Vocational education and training in the field of sport in the European Union: situation, trends and outlook. Lyon: European Observatoire of Sport and Employment.

45. $2017 \mathrm{~m}$. Lietuvos sporto statistikos metraštis. (2018). Vilnius: Kūno kultūros ir sporto departamentas. http://www.kksd.lt/index.php?1590309353 [2018-11-15]

Vilma Čingienè, Mindaugas Gobikas

\section{Viešosios sporto politicos formavimas hierachijos valdysenos kontekste}

Anotacija

Šio straipsnio tikslas yra išanalizuoti kaip Lietuvos sporto sistemos politikos formavimo proceso ypatumai pasireiškia hierarchinio valdymo kontekste, atitinka biurokratinę konfigūraciją ir sukuria objektyvias prielaidas decentralizacijai. Straipsnyje remtasi duomenimis, kurie buvo gauti renkant ir analizuojant oficialius dokumentus, susijusius su sporto viešosios politikos formavimu nuo $2011 \mathrm{~m}$. iki $2018 \mathrm{~m}$. Duomenų rinkimo tikslas buvo atskleisti pagrindinius viešosios politikos formavimo proceso komponentus - aplinką, strateginio planavimo procesą, dalyvių kompetenciją ir sprendimų prièmimo galią bei suinteresuotųjų šalių grupes. Pagrindiniai tyrimo rezultatai parodè, kad Lietuvos sporto valdymas kartu su daugeliu kitų Europos šalių apibrěžiamas kaip biurokratinė struktūra. Pagrindinè sporto viešosios politikos formavimo proceso atsakomybe tenka Švietimo, mokslo ir sporto ministerijai ir aktyvioms nevyriausybinèms sporto organizacijoms, o pagrindiniai Lietuvos sporto viešosios politikos formavimo tikslai išdèstyti strateginiuose dokumentuose. Tačiau jų igyvendinimas turètų būti paremtas institucine ir asmenine atsakomybe, pagarba ir tolerancija aplinkai, gebejjimu išklausyti ir susitarti.

Vilma Čingiene - Doctor of Social Sciences, is a Professor at the Institute of Leadership and Strategic Management, Faculty of Public Governance, Mykolas Romeris University.

email: v.cingiene@mruni.eu

Mindaugas Gobikas - PhD Student of Management at the Institute of Leadership and Strategic Management, Faculty of Public Governance, Mykolas Romeris University.

email: migobikas@stud.mruni.eu

Vilma Čingienè - Mykolo Romerio universiteto Viešojo administravimo fakulteto Lyderystès ir strateginio valdymo instituto profesorè, socialinių mokslų daktarè.

email: v.cingiene@mruni.eu

Mindaugas Gobikas - Mykolo Romerio universiteto Viešojo administravimo fakulteto Lyderystès ir strateginio valdymo instituto doktorantas.

email: migobikas@stud.mruni.eu 